УДК 398.2:821.161.1.

О. Б. Каневська, С. В. Щербак

\title{
МАЛІ ФОЛЬКЛОРНІ ЖАНРИ ЯК ФОРМА ВИРАЖЕННЯ НАЦІОНАЛЬНОГО ХАРАКТЕРУ
}

Каневська О. Б, Щербак С. В. Малі фольклорні жанри як форма вираження національного характеру.

У статті в лінгвостилістичному аспекті проаналізовані малі фольклорні жанри (лічилки, скоромовки, загадки), схарактеризовані їхні жанрові, ритмомелодичні, лексико-стилістичні та граматичні особливості, простежено відображення в них фрагментів національного колориту.

Ключові слова: усна народна творчість, лінгвостилістичний аналіз тексту, жанр, лічилки, загадка.

- 172 - О. Б. Каневська, С. В. Щербак, 2014. 
Каневская О. Б. Щербак С. В. Малые фольклорные жанры как форма выражения национального характера.

В статье в лингвостилистическом аспекте анализируются фольклорные жанры (считалки, скороговорки, загадки), охарактеризованы их жанровые, ритмомелодические, лексико-стилистические и грамматические особенности, рассмотрено в них описание фрагментов национального колорита.

Ключевые слова: устное народное творчество, лингвостилистический анализ текста, жанр, считалки, загадка. character.

Kanevska O. B., Shcherbak S. V. Small folklore genres as an expression of national

In an article in the theme aspect addresses the folklore genres (rhymes, tongue twisters, riddles), characterized by their genre, ritmologiya, lexico-stylistic and grammar covered in them opisanie fragments of national color.

Key words: folklore, linguostylistic analysis of a text, genre, counting-out rhymes, riddle.

Терміни «національний характер» $\mathrm{i}$ «менталітет нації» останніми роками $є$ активно використовуваними. Це підтвердження того, що не тільки філологічна наука загалом і іï розділи літературознавство, лінгвістика, фольклористика - зокрема, але й суспільство відчуває потребу у вивченні різних форм реалізації національного менталітету, співвідношення між менталітетом i національним характером, а також багатьох пов'язаних із цим понять. На думку С. Тер-Мінасової, саме «фольклор є найбільш надійним джерелом відомостей про національний характер. Сам факт, що тексти усної народної творчості не мають суб'єктивізму індивідуальноавторських творів, робить їх скарбницею інформації про характер народу» [7, с. 44].

Усе, що людина бачить перед собою, що потрапляє в людську свідомість, набуває форми слова. Мова як система знаків фіксує знання про світ, що оточує людину. Національний характер яскраво відображається в усній народній творчості: як у великих, так і в малих жанрах. Але питання щодо визначення специфічних національних рис, які знаходять відбиття в таких малих фольклорних жанрах, як загадка, скоромовка, лічилка, у сучасній науці дотепер повністю не розв'язане.

Актуальність теми нашої статті полягає в науковій цікавості сучасного літературознавства, фольклористики та лінгвістики до проявів національного менталітету в малих фольклорних жанрах (скоромовках, загадках, лічилках), відображення в них фрагментів національного колориту. 
Мета статті - порівняти художньо-образну структуру українських і російських малих фольклорних жанрів (скоромовок, загадок, лічилок). Простежити особливості вираження рис національного характеру українського народу в малих фольклорних жанрах.

Безперечно, одним із фольклорних жанрів, якому притаманне вміння володіти мовою, є скоромовка. Однак скоромовка на сьогодні недостатньо вивчена як у російській, так і в українській фольклористиці. Припускають, що перші скоромовки з'явилися ще в давній Русі, у них замальовувався побут, вірування, засоби пересування, тваринний світ і т. ін. Першим, хто зафіксував російськомовні скоромовки, був В. Даль. У книзі «Пословицы русского народа» (1862) знаходимо 49 текстів. Вивченню україномовних скоромовок сприяв В. Верховинець, який розглядав твори цього жанру як один із засобів формування національної культури молодого покоління. У скоромовках знаходимо слова різних тематичних груп, але передусім, пов'язані із землеробством (мак, просо, жито, морква, рожь тощо), сільським побутом (печь, мука, поле, борона тощо), наприклад: укр.: Якось Яків сіяв мак/Так-сяк, абияк./Визрів ярий Яків мак, / Та щось коле, як їжак [10]; рос.: Евсей, Евсей, муку просей,/А просеешь муку -/Испеки в печи калачи / Да мечи на стол горячи [6].

У скоромовках знаходимо вказівки на житло, предмети побуту, робочий інвентар, їжу, професію тощо: укр.: Водовоз віз воду 3 водопроводу. / Дрова рубали два дроворуби. / Босий хлопець сіно косить, / Роса росить ноги босі. / Семен сіно віз - не довіз: / Лишив сани - узяв віз [10]; рос.: Борона боронила неборонованное поле. / Возьми у белобородого мужика, / Полкринки кислого молока. / Соломы воз возница вез. / Дед Додон в дуду дупел,/Димку дед дудой задел. / Купили Валерику и Вареньке варежки и валенки [6].

В образній структурі багатьох скоромовок трапляються тварини: дикі звірі (ежик, волк, ведмідь, бобер), свійські тварини (баран, щенок, кошка, коза, бичок), птахи (гусь, цыплята, гагара, горобець, перепілка, сорока, ворона), екзотичні тварини та птахи (мавпа, попугай, черепашки), комахи (жук, мошка, джмелик, бджілка) та інші. Наприклад: укр.: Ведмедику-ледащчо, / Вліз на пасіку нащо? / Буду джмеликом дзижчати, / Буду меду куштувати. / Над квіткою гуде бджілка, / Сидить в житі перепілка, /На черешні горобець, / A хто зловить - молодець! / Хитру сороку / Спіймати морока, / А на сорок 
сорок / Сорок морок [10]; рос.: Говорил попугай попугаю: /«Попугай, попугай, я тебя, попугаю!» / Отвечает ему попугай: / «Попугай, попугай, попугай!» /На горе гогочут гуси. / Под горой огонь горит [6]. Проведене нами дослідження свідчить про наявність у російському й українському фольклорі однакових за змістом скоромовок (у такому разі можна припустити елементи калькування або близькість звичаїв і побуту споріднених народів). Порівняємо, наприклад, такі скоромовки: укр.: Був бик тупогуб, / Тупогубенький бичок / У бика була тупа губа [10]; рос.: Бык тупогуб, / тупогубенький бычок, / у быка бела губа была тупа [6]; укр.: Ішов Прокіп, кипів окріп, / прийшов Прокіп - кипить окріп, / як при Прокопі, так і при Прокопі $i$ при Прокопенятах / кипить окріп [10]; рос.: Пришёл Прокоп - кипит укроп. / Ушёл Прокоп - кипит укроп. / Как при Прокопе кипит укроп, / Так и без Прокопа кипит укроп [6].

Як уже зазначалося, одним із найбагатших і найяскравіших надбань багатовікової традиційної духовної культури будь-якого народу $є$ усна народна творчість. «Важко зрозуміти національний характер, національне мистецтво та літературу, не знаючи цього усного народного досвіду» [4, с. 200]. У цьому переконається кожен, хто матиме змогу ближче пізнати один із жанрів усної народної творчості загадки, як у живому побутуванні, так і ознайомитися 3 наявними публікаціями.

До наукового дослідження загадок в Україні в XIX ст. уперше звернулися О. Потебня, О. Сементовський, які пов'язували цей жанр із міфотворчістю. М. Сумцов шукав витоків загадок у церковній і художній літературі. Плідно займалися вивченням українських і російських загадок фольклористи та письменники, з-поміж яких: В. Аникін, І. Березовський, I. Колесницький, 3. Лановик, М. Лановик, М. Мельц, В. Митрофанова, I. Мокієнко, М. Пазяк, П. Попова, М. Рибникова, В. Топоров, Б. Успенський, І. Франко, Г. Шаповалова та ін.

За своєю формою народні загадки схожі до прислів’їв: те саме складне, ритмічне мовлення, часте використання рими та співзвуччя слів. Іноді лише питальна форма робить із прислів'я, приказки загадку: Сидит на овчине, а бьёт соболей (Промышленник) [5].

У загадках образи відображають світобачення, середовище, побут народу певної епохи: наперсток: Маленький хлопчик / Зліз на стовпчик, / Одежі не носить, / Їсти не просить, / Личенько рябе, / Що воно таке (укр.) [8]. - Шла свинья из болота, вся исколота (рос.) [5]; укр.: Утка в морі - хвіст надворі (Відро в колодязі); Прийшов сом та в кринищюю - 
бом (Відро на коромислі); Що дістане зубами потилищю (Гребінець) [8]; рос.: Летит птища перната: / Без глаз, без крыл, / Сама свистит, / Сама бьёт (Стрела); То толстеет, то худеет, на весь дом голосит (Гармонь); Чёрный кочет, рявкнуть хочет (Ружьё) [5].

Отже, загадки свідчать про тісний зв'язок міфології й усної народної творчості.

За тематикою загадки можна класифікувати таким чином:

1) артефакти (житло, предмети побуту, робочий інвентар): укр.: Поле скляне, а межі дерев'яні (Вікно); «Ой ви діти-квіти наші, наварю вам горшик каші, поїсте ви до смаку», - мовить бабка у кутку (Піч) [8]; рос.: Дерну, подерну по белому полотну (Окошко); Лето придет не глядят на него, зима настанет - обнимают его; Дедушка старый - Весь бельй (Печь); Мать толстая, дочь красная, сын кудреват, отец горбоват (Печь, огонь, дым, кочерга); Мать толста, / Дочь красна, / Сын храбер, / Под небеса ушел (Печь, огонь, дым) [5];

2) сільська праця: укр.: Стоїть сутула горбатий на все село багатий (Млин); Ходить пані по майдані, куди гляне - трава в'яне (Коса косить); Двадиять п'ять на одній лавці сидять (Борона); Літом служсть, а зимою зуби сушить (Борона) [8]; рос.: Один идет, четверых за собой ведет, а пятый сидит, в оба глаза глядит (Лошадь, телега, мужик); Меня бью, колотят, / Ворочают, редут, / Я всё терплю / И всем добром плачу (Земля пахотня); Матушкой весной - / В платнице ияетном, / Матушкой зимой - / В саване одном (Поле) [5];

3) людина як істота: poc.: Стоит город не на земле, не на воде, в том городе воевода спит (Ребенок в кольбели); Утром - на четырех ногах, в полдень - на двух, вечером - на трьох (Человек) [5];

4) частини тіла людини: укр.: Ой на горі-гай, під гаєм - мигай, nid мигаєм - сапай, під сапаєм - хапай (Голова) [8]; рос.: Кругленьким, маленьким до самого неба докину (Око); Горшочек умен, сем дырочек $в$ нем (Голова); Два Егорки живут возле горки, живут дружно, а друг на друга не глядят (Глаза); На скале сидит лягушка, а спрыгнуть не может (Нос); В темном подполье стадо белах лебедей (Зубы); Белье силачи рубят калачи, красный говорун подкладывает (Зубы и язык) [5];

5) явища природи: укр.: Гуркотить, стукотить, як сто коней біжить (Грім); Сивий віл випив води повен діл (Мороз); Без крил летить (Хмара); Сиві гуси усе поле вкрили (Туман) [8]; рос.: Заревел медведь на все горы, на все моря (Гром); Без рук, без ног, а рисовать умеет (Мороз); Без рук, без ног, А ворота отворяет; Рук и ног у него нет, / А всех трясёт и качает (Ветер); Долгая Арина по мосту 
ходила, / Ключи обронила, / Месяи видел, / Сонцее взяло (Роса); Летит огневая стрела, никто ее не поймает: ни царь, ни царица, ни красная девииа (Молния); Полная печь ватрушек, / В середине - один калач; Сивыи жеребец / Под вороть глядит (Месяи); Меня ждут не дождутся. / А как увидят - разбегутся (Дождь); Идёт, а ног нет, / Лежит, а постели нет, / Лёгкий, а крыши ломит (Снег) [5];

6) рослини: рос.: Этой баске сто лет, горба у неё нет, высоконько торчит, далеконько глядит, придет смерть за старушкой - станет бабка избушкой (Сосна); Стоит Егорка в красной ермолке, кто ни пройдет, всяк поклон подает (Земляника); Маленький, удаленький - сквозь землю прошел, красну шапочку нашёл (Гриб) [5];

7) овочі та фрукти: укр.: Без рук, без ніг, а пнеться на батіг (Квасоля); Баран у коморі, а роги надворі (Буряк); Хлопець Мартин / Похилився через тин. / А дівчина Гапка: / "Яка в тебе шапка! / Ще й жовта китиия / Проти сония світиться. / Як прилетять горобиі, / буде тобі, як вівиі / Від сірого вовка». / Що це за примовка? [8]; рос.: Зелёный телёнок привязан веревочкой, лежит на боку и толстеет (Арбуз); Жёлтая курица под тыном дуется(Тыква); Не шит, не кроен, а весь в рубцах (Капуста); Сидит барыня на грядках - вся в заплатках (Лук); Сидит баба на грядах, / Вся одежда в заплатах. / Кто ни взглянет, / Тот всплачет (Зеленый лук); Маленький, горький - луку брат (Чеснок); Круглая, а не месяи, жёлтая, а не масло, с хвостиком, а не мышь (Pепа) [5];

8) тварини (дикі та свійські), птахи: укр.: Пішла панна до міста; на ній суконь триста (Курка); Біле, як сніг, надуте, як міх, лопатами ходить, а рогом їсти (Гуска) [8]; рос.: Корова комола, лоб широк, глаза узеньки, в стаде не пасется и в руки не дается (Медведь); Серовато, зубовато, по полю рыщет, теляг, ягнят ищет (Волк); Под кустами, под ёлками катится клубок с иголками (Ёжик); Среди двора стоит копна, спереди вильл, сзади метла (Корова) [5];

9) комахи: укр.: Розгостився ткач в куточку, тче сіточку на смерточку рідній сестрі, близькій свасі - бідній мушиі й комасі (Павук); Хто мене вб'є - свою кров проллє (Комар) [8]; рос.: Летит воет, сядет - землю роет (Жук); Вокруг носа вьется, а в руки не дается (Муха); Черен, да не ворон, / Рогат, да не бык, / Шесть ног без копьт, / Идет - земли не дерет (Жук); Цельй день летает, / Всем надоедает, / Ночь настаёт, / Тогда перестаёт; Легко порхает, / Сама не знает; / Кто взглянет, / Всякий угадает (Муха); Остро, 
нековано, / Коснусь - поколано (Комар); В безлюдной тайге / Котелок кипит (Муравейник) [5];

10) знаряддя навчання та його результат: укр.: Чорний Іван, дерев'яний каптан: де носом проведе, там помітку кладе (Олівець); Тоненьке, кругленьке, / Серие чорненьке, / Хто на його слід погляне, / Думку його взнає (Олівець); Утрьох їуть братиі верхом на конячці (Пальці і олівець); Малий коник із чорного озерия воду бере та біле поле поливає (Перо, чорнило, папір); Біле поле, мудрий на нім оре; Біла рілля, чорне насіння; Лиш той посіє, хто розуміє (Папір, писання); Добре бачить, а сліпий (Неписьменний) [8]; рос.: Умный Ивашка - всю жизнь в одной рубашке (Карандаш); Хорошо видит, а слепой (Неграмотный) [5].

Проведений аналіз українських і російських загадок свідчить, що часто в основі їх художньо-образної структури покладено однаковий образ, його ознаки або дія. Наприклад, у загадках про замок - образ собаки, порівняємо: укр.: Хто не гавкає, не кусає, але й в хату не пускає [8]; рос.: Черная собачка свернувшись лежит: не лает, не кусает, а в дом не пускает [5]. Однокову дійову ознаку предмета покладено в основу загадок про пилку: укр.: Швидко гризе, дрібно жує, а сама не ковтає [8]; рос.: Зубастый зверек грызет с визгом дубок [5].

До середини XIX ст. дитячий фольклор не виділявся в окрему групу усної народної творчості та спеціально не записувався. Тільки від другої половини XIX ст. і у XX ст., відколи зростає зацікавленість суспільства народним життям, починається збирання та з'являються публікації зразків усної дитячої словесності В. Анікіна, О. Афанасьєва, В. Василенка, В. Верховинця, Г. Виноградова, М. Вовчка, В. Даля, П. Іванова, С. Ісаєвича, О. Капіци, М. Лисенка, I. Манжури, М. Мєльнікова, П. Шейна, П. Чубинського, Д. Яворницького та ін.

Більшість фольклористів указує, що лічилка виникла в глибокій старовині як засіб розподілу на роботу, яка за тих часів була не тільки важкою, а й небезпечною для життя людини. Ї̈і використовували в реальному житті, тому лічилка $\epsilon$ не самостійним літературним жанром, а прикладним, оскільки має практичне завдання: укр.: Ходить бусол по болоту / Кличе хлопців на роботу. / Хлопиі кажуть не хочу! / Бусол каже - заплачу! [9]; рос.: Сидел петух на лавочке, / Считал свои булавочки. / Раз, два, три - / Выходи, булавка, тыл!; 3 а стеклянными дверями / Еж торгует пирогами. / Пирожок недорог - / Сточт рубль сорок; Шла кукушка мимо сети, / А за нею-маль дети. 
/ Кукушата просят пить. / Выходи - тебе водить! [4].

Є припущення, що лічилки походять від мисливського жеребкування, пов'язаного 3 ворожінням: «пощастить» / «не пощастить», із магічними заклинаннями, що мали принести удачу під час полювання. Тому лічилки за звуковою й синтаксичною структурою нерідко схожі до заклинань: укр.: Сітка, вітка, / дуб, дубки - / поставали козаки, / Шабельками брязь - / вийди, князь. / Ігдики, ичигдики, / цчидики де, / Абель, фабель, / дурмане, / Ікі, тікі, граматікі, / Ои, / клац, / заєцьь [9]; рос.: Эни, бени, рики, таки, / Турба, урба, синтибряки, / Эус, бэус, краснобэус, / Бац! / Эни, бени, рики, факи, / Турба, урба, эки, факи, / Эус, бэус, космобэус, / Баи! / Эни, бени, рики, паки, / Буль-буль-буль, каляки, шмаки, / Эус, бэус, космобэус, / Баи! / Эни, бени, рики, факи, / Тиль, буль-буль, корики, шваки, / Деус, деус, космодэус / Бащ! [4] (заумна лічилка побудована на варіюванні звуків). Мотиви заклинань також знаходимо, наприклад, у такій українській лічилці: Один, два, три, / Ти до мене не ходи, / Бо у мене чорний пес, / Як тя вкусить, то умреш [9].

Національний колорит відбивається:

1) у тематиці лічилок: укр.: Tapapax, mapapax, / ̈̈де Хома на волах. / На яких? - На рябих. / - На чиїх? - На Мартинових [9]; рос.: За морями, за горами, / За железными столбами, / На пригорке теремок, / На дверях висит замок. / Ты за ключиком иди / И замочек отомкни [4];

2) у використанні власних імен: укр.: Тарас, Ганнуся, Парася і т. ін.: Йшла Маринка по стежинці, / Загубила там корзинку. / A в корзинці паляниця, / Хто з'їв - тому жмуриться! [9]; рос.: Ваня, Ванечка, Иван, Мишка, Мишенька, Борис, Дима, Иринка, Маринка, Лариса, Елена і т. ін.: Раз, два, три, четыре, пять, / Шесть, семь, восемь, девять, десять, / Царь велеу 18 тебя повесить. / Я висеу, висеу, висеу, / И на небо улетеу. / Прямо, прямо, прямо, / Там большая яма, / Две ступеньки вниз, / Там живет Борис, / Председатель дохльх крыс; За стеклянными дверями / Сидел Мишка с пирогами. / Мишка, Мишенька, дружок, / Сколько стоит пирожок? / - Пирожок мой стоит три, / А голить-то будешь тьл! [4];

3) у використанні найменувань жителів: укр.: русини, подоляночка; рос.: немец, француз;

4) у використанні специфічних, властивих національному побуту слів: укр.: вареник, книш, палянищя, постольці, паџьори; рос.: терем, пироги, рукавица, машина, лавочка, булавочка, ружьё. 
У тематиці багатьох українських лічилок відображено риси сільського побуту, сільської праці: Йшла собака через міст - / чотири лапи, / n'ятий хвіст. / Стоїть півень на току / у червонім чобітку / Будем півника просити: / ходи жито молотити; На городі бараболя, / Кабаки, / Буряки, / Редька, морква, огірки, / Пастернак, / Повний мак. / А ми кошичка візьмем / Та повнінький наберем. / Хто піде, / Той візьме [9].

Важливою складовою частиною художньо-образної структури лічилки є іiі символізм, пов'язаний передусім із небесною сферою: укр.: Покололо, покотило, / По дорозі волочило, / Сонце, місяць $i$ зірки, / На кілочку вийдеш ти; Летіла лелека, / Летіла здалека, / Та й сіла на хаті / Зірки рахувати. / Не їла, не спала, / Всю ніч рахувала, / A вдосвіта збилась, / Зоря покотилась, / Упала додолу / На піжмуриі в колу [9]; рос.: Катилося яблочко по огороду / И упало прямо в воду. / Бульк! / Вода-красная заря! [4].

Лічилки відрізняються одна від одної не лише сюжетом, але й персонажами. Проведений аналіз текстів дозволяє поділити всіх персонажів лічилок на такі тематичні групи:

«люди»:

1) характеристика за статтю, віком, родинними відносинами: хлопиі, дівчатки, дівчаточка, дівка, баба, дід, діти, діточки, діткиоднолітки, малята, брат, мама;

2) характеристика за міжособистісними стосунками: друзяки, друзі;

3) соціальним положенням: князь, козак, цариця, мужик, пан, пані, господиня;

4) характеристика за національністю, місцем проживання: подоляночка, полька, циганка, русини;

5) власні імена: Сидір, Каленик, Павло, Павлик, Марко, Мартин, Хома, Іван, Йван, Роман, Василь, Тарас, Грищъь, Віталій, Федір; Парася, Марія, Марічка, Маринка, Тетянка, Федора, Ганнуся, Настя; «звірі»:

1) загальна назва: звірі;

2) дикі: заєць, зайчики, ведмідь, лис, мишка, їжачок;

3) свійські: кіт, котик, кабанці, свині, воли, корівка, телятко, баран, коза, козенятко, цап, цүапок, пес, собака, коник, коні;

\section{«птахи»:}

1) загальна назва: птахи, пташата;

2) дикі: бусол, лелека, чижик, зозуля, зозулиця, сова, совонькасова, крук, горобчики; 
3) свійські: курочка, півник, гусаки, качка, качатко; «земноводні, риби»:

1) земноводні: жаба, жабенята;

2) риби: щука-риба;

«комахи»: равлик, метелик, павучок, бджілка, джміль, оса. «рослини»:

1) загальна назва: трава, травичка, квіточки;

2) дикорослі: дуб, верба, горіх, в'яз, лоза, падолист, тополя, калина, барбарис, сунички, лобода, будяки;

3) сільсько-господарчі: жито, житечко, редька, морква, огірки, пастернак, мак, буряки, кабаки, бараболя, горох.

Отже, проаналізувавши малі фольклорні жанри (скоромовки, загадки, лічилки) можемо зробити висновок, що в них відображаються певні особливості світосприймання українського та російського народів, вони відіграють винятково важливу роль у їхньому духовному житті, функціонують у поєднанні з кращими надбаннями народнопоетичної традиції минулого 3 новими явищами, породженими життям, помислами, настроями, переживаннями, ідеалами й естетичними потребами сучасної дитини.

\section{Література}

1. Войнович В. Українська міфологія / В. Войнович. - К. : Либідь, 2002. - 664 с.

2. Лановик М. Українська народна словесність: [посібник для студентів гуманітарних ф-тів ВНЗ] / М. Лановик, 3. Лановик. - Львів: Літопис, 2000. - 614 с.

3. Мельников М.Н. Русский советский фольклор : [ учебное пособие для студентов пединститутов] / М. Н. Мельников. - М. : Просвещение, 1987. - 240 с.

4. Русское народное поэтическое творчество. Хрестоматия. - Л. : Просвещение, Ленинград. отд-ние, 1987. - 655 с.

5. Русские народные загадки [Электронный ресурс]. - Режим доступа : http://ulin.ru/riddle.htm

6. Русские народные скороговорки [Электронный ресурс] / Режим доступа : http://www.natalimak1.narod.ru

7. Тер-Минасова С. Г. Война и мир языков и культур. Вопросы теории и практики межъязыковой и межкультурной коммуникации : [учебное пособие] / С. Г. ТерМинасова. - М. : АСТ-Астрель-Хранитель, 2007. - 288 с.

8. Українські народні загадки [Електронний ресурс]. - Режим доступу : uti-puti.com.ua

9. Українські народні лічилки [Електронний ресурс]. - Режим доступу : uti-puti.com.ua

10. Українські народні скоромовки [Електронний ресурс]. - Режим доступу : http://traditions.org.ua 